Isidora Ljumović ${ }^{1}$, Vladan Pavlović ${ }^{2}$, Janko M. Cvijanović ${ }^{3}$
JEL: G21, G29, L16

DOI: 10.5937/industrija42-5867

UDC: $336.71(497.11) 336.76$

Original Scientific Paper

\title{
Two Aspects of Concentration in Serbian Banking Sector ${ }^{4}$
}

\author{
Article history: \\ Received: 4 April 2014 \\ Sent for revision: 9 April 2014 \\ Received in revised form: 10 June 2014 \\ Accepted: 23 July 2014 \\ Available online: 1 November 2014
}

Abstract: This paper aims to approach concentration in the banking industry from two perspectives. Broader analysis shows that capital markets are underdeveloped and that Serbian financial system is bank based. Analysing the concentration from a more narrow perspective, authors concluded that the banking sector in Serbia is characterized as a highly fragmented one, but the reduction in number of banks did not lead to an increase in the concentration of any of the analysed parameters, thus the level of concentration is moderately low. Detail analysis of selected countries was performed as comparative analysis. Unfortunately, it was impossible to make a universal conclusion about whether reducing the number of banks affects positively or negatively the level of concentration.

Key words: bank concentration, bank-based systems, bank consolidation, Herfindahl-Hirschman Index, Concentration ratio

\section{Dva aspekta koncentracije srpskog bankarskog sektora}

Apstrakt: Ovaj rad ima za cilj da analizira koncentraciju u bankarskom sektoru iz dva ugla. Šira analiza pokazuje da je tržište kapitala nerazvijeno $i$ da je finansijski sistem Srbije zasnovan na bankama. Analizom koncentracije u užem smislu, autori su zaključili da bankarski sektor Srbije karakteriše visok stepen fragmentacije, ali smanjenje broja banaka nije dovelo do povećanja koncentracije bilo kog od analiziranih parametara, tako da je nivo koncentracije umereno nizak. Da bi se izvšila uporedna analiza, istraživani su

\footnotetext{
${ }^{1}$ Economic Institute, Belgrade, isidora.ljumovic@ecinst.org.rs

${ }^{2}$ University of Priština, Economic Faculty, temporary seated in Kosovska Mitrovica,

${ }^{3}$ Economic Institute, Belgrade

${ }^{4}$ This paper is a part of the results within research on project 179001 , financed by Ministry of education, science and technological development of the Republic of Serbia
} 
Ljumović I. et al.: Two Aspects of Concentration in Serbian Banking Sector

pomenuti fenomeni i kod odabranih zemalja. Nažalost, nije bilo je moguće da se donese univerzalni zaključak o tome da li smanjenje broja banaka utiče pozitivno ili negativno na stepen koncentracije.

Ključne reči: koncentracija banka, bankocentrični finansijski sistem, konsolidacija banaka, Hirfindal - Hiršmanov indeks, racio koncentracije

\section{Introduction}

Over the past few decades banking sectors in developed and developing countries have experienced significant changes in their operating environment. It is considered that these global changes have occurred under the influence of different factors such as emergence of new technologies, liberalization and deregulation of financial markets, global integration of capital markets and regulatory initiatives at the international level. This set of external and local factors changed the structure and performance of banking systems worldwide. Serbian banking market where banks are still dominant financial institutions was also affected by these changes. Bearing in mind that banks play a central role in financing economic activity, stable and profitable banking sector is a necessity.

When going through transformation of their banking sector all transitional countries undergo significant changes first in the ownership structure where the participation of foreign banks in the credit portfolio, deposit potential, assets and equity of the banking sector is increased. This process of increasing participation of foreign banks, the so-called process of internationalization appears as a feature of almost all banking systems in transitional countries. Incentives for consolidation of the banking system in transition countries coincide with the supportive factors of bank internationalization. Inflow of foreign investment brings the increase in concentration and reduction in the number of banks operating in country. The process of internationalization of the Serbian banking sector in relation to the level of competition is characterized by three phases. During the first phase the licensing policy to local and foreign banks was liberal. Foreign banks had no restrictions in establishing subsidiaries in Serbia. Four banks took the advantage: AlphaBank, National Bank of Greece, Raiffeisen Bank and Microfinance (now Pro Credit) ${ }^{5}$ increasing the number of banks operating in Serbia by four. During the second phase Serbian monetary authorities changed their strategy significantly and the entry of foreign banks was possible only through the purchase of the existing ones. The number of banks has been reduced from 49 to 35 (because some foreign banks bought up to a

\footnotetext{
${ }^{5}$ Common misconception is that Societe Generale entered the Serbian market at this time.
} Actually it operated in Serbia since 1992. 
few banks - good example is OTP Bank, which bought Zepter, Kulska and Niška bank). At the same time more than $75 \%$ of the banking sector was acquired by non-residents, foreign banks. The third stage of internationalization is characterized by the return to the liberal licensing policy. At this stage, the number of banks has not significantly changed since the only bank that has entered the market was Moscow bank. Although banking market was already saturated and accounting bad performance of Serbian economy, entry of new banks was not to be expected. However entry of Russian bank came as a consequence of public policy and privatization of Serbian oil company - NIS.

In economic theory, it is considered that concentration is an important determinant of market structure, market behaviour and results attained in this particular market. Concentration in banking sector is often examined in relation to other elements such as the level of competition, the stability of the banking system, the emergence of the crisis and other factors. However, this paper focuses on the analysis of concentration in the banking sector of Serbia through a set of commonly used indicators. According to many authors (among them Ljubaj 2005) these indicators are quite sufficient in analysing concentration in the banking sector.

After this introduction, the next chapter represents overview of the relevant scientific literature and the analyses of concentration from two perspectives the broad and narrow definition. Within this part methodology was presented and data were analysed. Results and discussion are presented in the third chapter. The conclusion shows that despite a significant decrease in the number of banks in the analysed period, a major increase in the degree of concentration has hot occurred.

\section{Literature review and methodological framework for research}

The consolidation process is not unique to developing and transitional countries as it intensively emerged in developed countries much earlier. As a consequence there are numerous studies that are analysing concentration in banking sectors of developed countries and recently in the last decade or two these analysis are more common in developing countries. Also, there are a number of studies conducted on a multi-countries sample.

The literature shows considerable controversy as to whether the reduction in the number of banks leads or does not lead to a significant increase in the concentration. Among the first who explored this phenomenon were Berger and Hannan (1989). These authors argue that increase in the concentration, raises interest margins and therefore bank profitability. They also claim that 
the efficiency of the banking sector will increase if the system is concentrated. To support this hypothesis they state that more efficient banks grow faster - in other word, more efficient banks are taking over the ones less efficient. Subsequent research from Gelos and Roldós (2004) conclude that reducing the number of banks does not necessarily lead to an increase in concentration. The authors of the study explored the phenomenon of concentration on set of data from the banking sector across Central Europe. Their results show that the both number of banks and concentration decreased, as the former state-owned banks with significant market share, lost this share due to the dominance of medium-sized banks which were much more adaptable to the environment. Also, this study compares banking sectors across Central Europe with Asian and Latin American. In Asian countries, the number of banks has declined due to the privatization of the banking sector, but also the degree of concentration decreased. The trend of increasing competition, due to the reduced number of banks was identified only in Latin America. However, the authors of this study believe that this is due to early entry of foreign capital, and state that this concentration is often accompanied by banking crises (Gelos\&Roldós 2004, pp. 40-41). The most extensive study conducted in Latin America identified the trend of reducing the number of banks, but also a trend of increasing concentration (Levy\&Micco 2007, p. 1645). The authors of this study have concluded that increased concentrations did not result in reduction of competition, but that the direct cause was the premature entry of foreign banks, which was subsequently reflected in the high degree of risk and volatility in the banking system. In Serbia several researches were conducted. All of them show that concentration in banking sector is moderate despite decrease in the number of banks (Marinković 2006, 2007, Lončar and Rajić 2012, Miljković, et al. 2013, Barjaktarović et al. 2013).

It is already mentioned that the research of concentration is often associated with other factors. The most commonly analysed relationship is the link between concentration and competition. Although at first glance these are the opposite concept, as an increase in the concentration should reduce the competition because of a smaller number of market participants, in practice, this has not been confirmed. Some studies confirm contradictory that the concentration and competition are positively correlated and that more concentrated systems are more competitive (for details, see Claessens\&Laeven 2003; Demirguc-Kunt et al. 2004; Shaffer 1993; Nathan\&Neave 1989, for Canada, Mamatzakis et al. 2005 for the region of South-Eastern Europe). Study from Mamatzakis et al. (2005), where they applied Panzar-Rosse model to examine the concentration in the banking markets of South East Europe has important implications for this paper. The authors concluded that although all of the analysed countries went through a period of consolidation, number of banks and the level of concentration have 
decreased. Another conclusion has important implication for Serbian banking market. These authors came to the conclusion that in analysed markets banking margins and earnings are equal to those obtained in the monopoly system, but on the other hand the concentration level is moderate. The authors however limit their research because studies performed in one period do not necessarily have to reflect to the next period (Mamatzakis et al 2005, p. 207). In contrast to these studies Jansen and DeHaan (2003) failed to find a link between concentration and competitiveness across the European Union. Schaeck et al (2009) argue that the concentration and competition are not linked and that the concentration is often misused as a proxy for competition.

Concentration may greatly affect the stability of the financial system. Certain researches have shown that market concentration has a negative impact on financial stability (Heimeshoff and Uhde 2009). Research from Heimeshoff and Uhde (2009) showed that the market concentration is directly related to the return on average assets (ROAA) which directly suggests that banks with higher market share achieved above-average yields. The link between the crisis and the concentration is analysed in Beck et al. (2006) on a sample of 69 countries for the period 1980-1997. The authors argue that it is less likely for the occurrence of crises in those countries where the banking system is more concentrated. Even when the variables, such as bank regulatory policy, macroeconomic conditions and economic shocks are included, the authors obtained the same results.

In this paper we use the term concentration according to the research needs of this subject in Serbia. For having readers, who are not banking professionals but may potentially seriously use conclusions on the concentration of banks in Serbia (managers at various levels in the public administration and the economy), better understand the findings of the study, we have to point out that all meanings of the term concentration are stemming from the Latin word which in Serbian basically means thickening/densification. This concentration can be a thickening of the solution (in chemistry), attention and focus on one topic (in communication), the preferred ingredient in the ore (metallurgy), human, technical, financial and other resources in the enterprise or in the region (in the economy), etc. As a rule, it refers to the average value of the densifying objects and almost always is the relation between the object and the subject of concentration at a given time in a defined area. Usually the uniformity of concentrating object distribution is not taken into account and it is usually even implied that the uniformity is inherent to concentration which is usually far from the truth ${ }^{6}$. In any case it is acceptable for every profession

\footnotetext{
${ }^{6}$ At the Bežanijska Kosa area, Novi Beograd, in one street at a distance of less than $1 \mathrm{~km}$ eleven different banks are "concentrated". This fact points to many other aspects of the position of the banking sector in Serbia.
} 
and science to have their own slang terms often used with the opposite meaning from the colloquial one and from the meaning they have in other professions and sciences (Adzic et al, 2005). To certain extent it is the case with some of the terms in this paper.

Concentration in the banking industry can be approached from two perspectives. In its original form, in a more narrow sense, concentration includes bank consolidation through mergers, acquisitions and joint ventures. In a broader sense, it means a lot more, and primarily is manifested as a desire to attract and concentrate more resources into the banking sector. Actually, this implies the majority of assets in the banking sector, rather than in other parts of the financial sector (bank-based financial systems). Therefore, the concentration in broader sense refers to the share of the banking sector in the financial system, while a more narrow definition of concentration deals with the function of the number of banks and their respective share in the banking sector. First definition specifies the type of the financial system, while the second shows the market structure of the banking sector. When analysing concentration in the banking sector, it usually involves only more narrow definition and as such it is used in the majority of the research. Previous research and analysis have focused on concentration from a more narrow perspective, and a broader analysis is very often lacking. However, in this paper we choose to analyse also the broader definition of concentration, because it is not the same to analyze the concentration (according to more narrow definition) in the bank-based systems and in those based on the capital markets. It makes sense that the analysis of the concentration according to more narrow definition has greater importance in bank-based financial systems, especially in those where the capital market is underdeveloped and illiquid.

In this paper we have used several databases which we crossed for research purposes. In the section that analyzes the concentration in a broader sense we used database of the National Bank of Serbia and the Belgrade Stock Exchange, which are available on their official websites. For the part of the paper dealing with the definitions in more narrow sense, we used the database of the ECB (mainly the EU Banking Structure), the Croatian National Bank database for Croatia, National Bank of Serbia and BankScope database - a comprehensive, global database of banks' financial statements, ratings and intelligence. All these databases are available on official websites, beside the BankScope database.

\subsection{Concentration analysis in a broader sense - the concentration of assets in the banking sector}

When analysing concentrating in a broader sense, it is usually expressed as the structure of the financial system. If the financial system is highly 
concentrated in terms of the majority of assets in the banking sector, it is often said that this financial system is bank-based. On the other hand, if there is greater assets concentration in the financial markets, it is referred to the financial system based on the capital market. The literature and practice lack the stand about what way of organizing the financial system is better (for details, see Chakraborty and Tridip 2006, Ergungor 2004, Levine 2002). In fact, it is considered that there is a difference in a way of organizing due to tradition and financial regulation, and the literature often emphasizes the quality and availability of financial services to the users of the entire system. Having this in mind we set the first hypothesis as:

Despite significant changes in the banking sector, the structure of the financial system has not changed drastically.

A more detailed analysis of the financial system of Serbia in relation to the concentration in the broad sense is possible only after 2007. Unfortunately, data on the previous period is not available.

Table 1. Belgrade Stock Exchange indicators

\begin{tabular}{clll}
\hline Year & Turnover (RSD) & No of transactions & Market capitalization (RSD) \\
\hline 2006 & 100.583 .951 .914 & 141.499 & 809.020 .645 .353 \\
2007 & 164.990 .865 .957 & 301.210 & 1.440 .485 .344 .701 \\
2008 & 71.853 .776 .130 & 119.001 & 916.594 .847 .270 \\
2009 & 41.778 .491 .982 & 77.215 & 932.332 .706 .604 \\
2010 & 23.017 .197 .757 & 725.550 & 933.465 .974 .978 \\
2011 & 28.584 .502 .604 & 2.887 .538 & 817.461 .701 .758 \\
2012 & 24.988 .496 .333 & 483.013 & 776.195 .053 .684 \\
\hline
\end{tabular}

Source: Annual statistics, Belgrade Stock Exchange

The importance of the capital market is determined by the number of listed companies and by the market capitalization (Table 1). However, the number of companies listed on the Belgrade Stock Exchange (BSE) and the level of market capitalization does not reflect the reality. As a consequence of secondary market underdevelopment, basic prerequisites for companies to obtain equity by issuing stocks do not exist and financial markets have almost no relevance in the financing of the Serbian economy. The important specificity of the BSE is that it emerged in the context of privatization. Without knowledge of the Serbian economy privatization, situation, development and operation of the BSE cannot be understood. A large number of companies listed on BSE is not the result of a developed capital market but a consequence of the chosen model of privatization and the forced inclusion of the companies to the stock exchange. This resulted in a large number of inactive companies. (for details see: Pavlovic and Muminović 2010) If we analyze capital markets In Serbia, corporate bonds market almost does not exist. Borrowing by issuing bonds is marginalized and enterprises largely 
Ljumović I. et al.: Two Aspects of Concentration in Serbian Banking Sector

depend on the banking sector, where they borrow. (Pavlovic and Muminović 2010)

Analysis of the concentration in banking is performed for the period 20072012 and it shows that the financial system is bank-based since more than $90 \%$ of the assets is concentrated therein (previous discussion about capital markets and Table 2). Participation of banks in total assets was relatively constant throughout the analysed period, with a slight tendency of increase.

Table 2. The structure of the financial system for the RS, market share (in \%)

\begin{tabular}{lllllrrrrrr}
\hline & 2003 & 2004 & 2005 & 2006 & 2007 & 2008 & 2009 & 2010 & 2011 & 2012 \\
\hline Banks & $\mathrm{n} / \mathrm{a}$ & $\mathrm{n} / \mathrm{a}$ & $\mathrm{n} / \mathrm{a}$ & $\mathrm{n} / \mathrm{a}$ & 90,2 & 89,3 & 90,8 & 91,8 & 92,4 & 92,7 \\
Financial leasing & $\mathrm{n} / \mathrm{a}$ & $\mathrm{n} / \mathrm{a}$ & $\mathrm{n} / \mathrm{a}$ & $\mathrm{n} / \mathrm{a}$ & 5,5 & 6,2 & 4,7 & 3,6 & 2,8 & 2,3 \\
Insurance & $\mathrm{n} / \mathrm{a}$ & $\mathrm{n} / \mathrm{a}$ & $\mathrm{n} / \mathrm{a}$ & $\mathrm{n} / \mathrm{a}$ & 4,1 & 4,3 & 4,2 & 4,2 & 4,4 & 4,5 \\
Pension funds & $\mathrm{n} / \mathrm{a}$ & $\mathrm{n} / \mathrm{a}$ & $\mathrm{n} / \mathrm{a}$ & $\mathrm{n} / \mathrm{a}$ & 0,2 & 0,2 & 0,3 & 0,4 & 0,4 & 0,5 \\
\hline TOTAL & $\mathrm{n} / \mathrm{a}$ & $\mathrm{n} / \mathrm{a}$ & $\mathrm{n} / \mathrm{a}$ & $\mathrm{n} / \mathrm{a}$ & 100 & 100 & 100 & 100 & 100 & 100 \\
\hline
\end{tabular}

Source: NBS (2003-2012). Annual report

If we look at the total assets of different types of financial intermediaries, there is a very dynamic growth in the banking sector (Table 3). In the period 20072012 , which is comparable in all types of financial intermediaries, it is evident that the banking sector and the insurance companies doubled total assets. Providers of financial leasing had large fluctuations in the amount of total assets and in 2012 this amount was lower than in 2007. Voluntary pension funds have the most dynamic asset growth from 3 to 16 billion dinars (800\% in five years).

Table 3: The structure of the financial system for the RS, total assets (in billions RSD)

\begin{tabular}{lccccrrrrrr}
\hline & 2003 & 2004 & 2005 & 2006 & 2007 & 2008 & 2009 & 2010 & 2011 & 2012 \\
\hline Banks & 367 & 510 & 775 & 1169 & 1564 & 1777 & 2160 & 2534 & 2650 & 2879 \\
Financial leasing & $\mathrm{n} / \mathrm{a}$ & $\mathrm{n} / \mathrm{a}$ & $\mathrm{n} / \mathrm{a}$ & $\mathrm{n} / \mathrm{a}$ & 95 & 123 & 111 & 99 & 80 & 72 \\
Insurance & $\mathrm{n} / \mathrm{a}$ & $\mathrm{n} / \mathrm{a}$ & $\mathrm{n} / \mathrm{a}$ & $\mathrm{n} / \mathrm{a}$ & 70,6 & 84,8 & 99,2 & 117,1 & 125,7 & 140,5 \\
Pension funds & $\mathrm{n} / \mathrm{a}$ & $\mathrm{n} / \mathrm{a}$ & $\mathrm{n} / \mathrm{a}$ & $\mathrm{n} / \mathrm{a}$ & 3 & 4,64 & 7,2 & 9,8 & 12,5 & 16 \\
\hline TOTAL & $\mathrm{n} / \mathrm{a}$ & $\mathrm{n} / \mathrm{a}$ & $\mathrm{n} / \mathrm{a}$ & $\mathrm{n} / \mathrm{a}$ & 1733 & 1989 & 2378 & 2759 & 2868 & 3108 \\
\hline
\end{tabular}

Source: NBS (2003-2012). Annual report 
Ljumović I. et al.: Two Aspects of Concentration in Serbian Banking Sector

\subsection{Analysis of the concentration in more narrow sense - data and methodology}

The analysis of concentration in more narrow sense was conducted for the period 2003-2012. During the data analysis, there was an evident problem regarding the quality of the data. For the period prior to 2003, it was impossible to collect valid data that could be meaningfully interpreted. In the period 2003-2007, the National Bank of Serbia did not perform the analysis of the concentration and the authors made their own calculations using a BankScope database. Since no meaningful data are available, it is necessary to elaborate on the period prior to 2003 during which significant changes in the structure of the banking system in Serbia happened. In 2001, there were dynamic changes and the number of banks in this period was drastically reduced. More than 40 banks were closed, among them 19 banks lost their license to operate, 4 banks were given the deadline for recapitalization, 5 banks were in the process of rehabilitation, in one bank administrative measures were introduced, 5 banks were in the category of troubled banks, 17 banks were under measures for adjusting performance indicators, while 18 banks were merged with other banks (Narodna banka Jugoslavije 2001, p. 87). Having assessed the general condition of the banking sector in Serbia (then Yugoslavia), monetary authorities estimated that there are problems with four large state-owned banks, which possessed $57 \%$ of total assets of the entire banking sector. Although the original plan envisaged the rehabilitation of these banks, the National Bank of Serbia made the decision in 2002 that these banks should be liquidated. In 2002, the first foreign bank bought domestic bank, Depozitno - Kreditna Bank AD Beograd, and the trend of reducing number of banks was continued on the same basis as in the previous year.

When choosing concentration indicators, we were guided by the research from Ljubaj (2005), who concluded that only a few representative indicators, the Herfindahl-Hirschman Index $(\mathrm{HHI})$ and the ratio of the concentration are enough for quality analysis. Other relevant studies also use these indicators. Here we have set out our second hypothesis:

Reducing the number of banks in Serbia has not led to an increase in the degree of concentration measured by the $\mathrm{HHI}$ and $\mathrm{CR}_{5}$ index.

$\mathrm{HHI}$ is a standard measure of concentration in any industry. This index is the sum of squared market shares of the market participants, and is considered to be the most reliable indicator of competition because it gives proportionately greater importance to the market share of large firms. Market share in the banking industry can be approached from many different aspects where balance sheet (observed in relation to the share of deposits or loans) is the most common and most important one. This simple tool shows the 
concentration of the whole sector. If the values are between 1000 and 1800 (from 0.1 to 0.18 ) the market is moderately concentrated. Values over 1800 (above 0.18 ) show that the market is highly concentrated, and in a situation where the index is less than 1000 (0.1) there is no concentration. Among other things $\mathrm{HHI}$ is considered to be an appropriate indicator as it responds very well to companies with large market share, since square sum of shares of certain companies is used. $\mathrm{HHI}$ is therefore calculated using the following formula:

$$
H=\sum_{i=1}^{N} S i^{2}
$$

where:

$\mathrm{Si}$ - market share of bank $i$ (chosen indicator)

$N$ - number of banks.

In addition to $\mathrm{HHI}$, market share of the five largest banks (CR5) is used. This indicator is calculated as the sum of the market share (in terms of assets, loans and deposits) of top five banks. Among other things, this indicator is used for comparability with other countries in the region. Concentration ratio is calculated based on the following general formula:

$$
C R_{n}=\sum_{i=1}^{n} t_{i}=t_{1}+t_{2}+\ldots+t_{n}
$$

where:

$t_{i}$ is market share of the $i$ company ranked by size from largest to smallest, in the given number of companies (banks) $n$

$t_{i}$ is calculated based on the following formula:

$t_{i}=\frac{q_{i}}{Q}$

where

$q i$ is offer from the $i$ bank and $Q$ is offer from the entire branch.

A common feature of these two indicators is that lower values indicate a lower level of competition. 


\section{Empirical results of research and discussion}

In general, the banking sector in Serbia is characterized as a highly fragmented, because there is large number of banks with a market share lower than $2 \%$ in the most important categories (total assets, loans and deposits). Fig. 1 shows the trend of the $\mathrm{HHI}$ in relation to total assets, credit and deposit activity (left axis) and number of banks (right axis). It is obvious that reduced number of banks did not necessarily lead to an increase in the concentration of any of the three analysed parameters. The level of concentration is moderately low because it has not exceeded the level of 1000 in any of the analysed years.

Figure 1. HHI in Serbia in the period 2003-2012

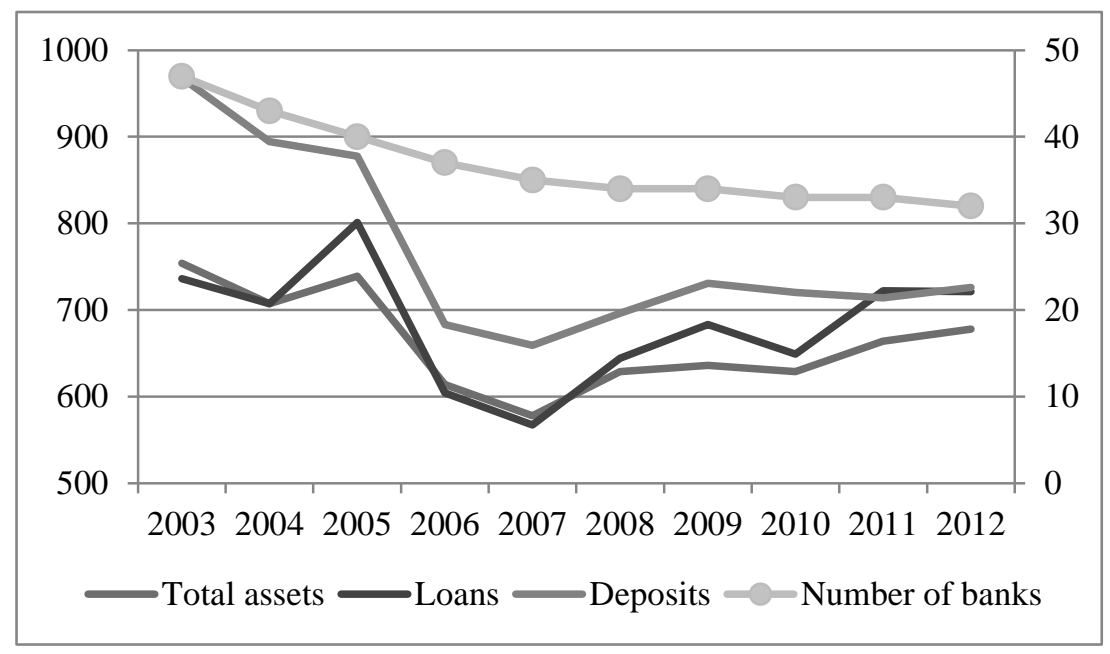

Source: NBS (2007-2012). Annual report and authors own calculation for 2003-2006

The Fig. 2 shows another indicator of concentration - the concentration ratio of the five largest banks in Serbia. The left axis indicates the level of concentration, while the right axis indicates the number of banks. The results obtained by this indicator largely coincide with the results of the Fig. 1. 
Ljumović I. et al.: Two Aspects of Concentration in Serbian Banking Sector

Figure 2. CR5 for Serbia in the period 2003-20012

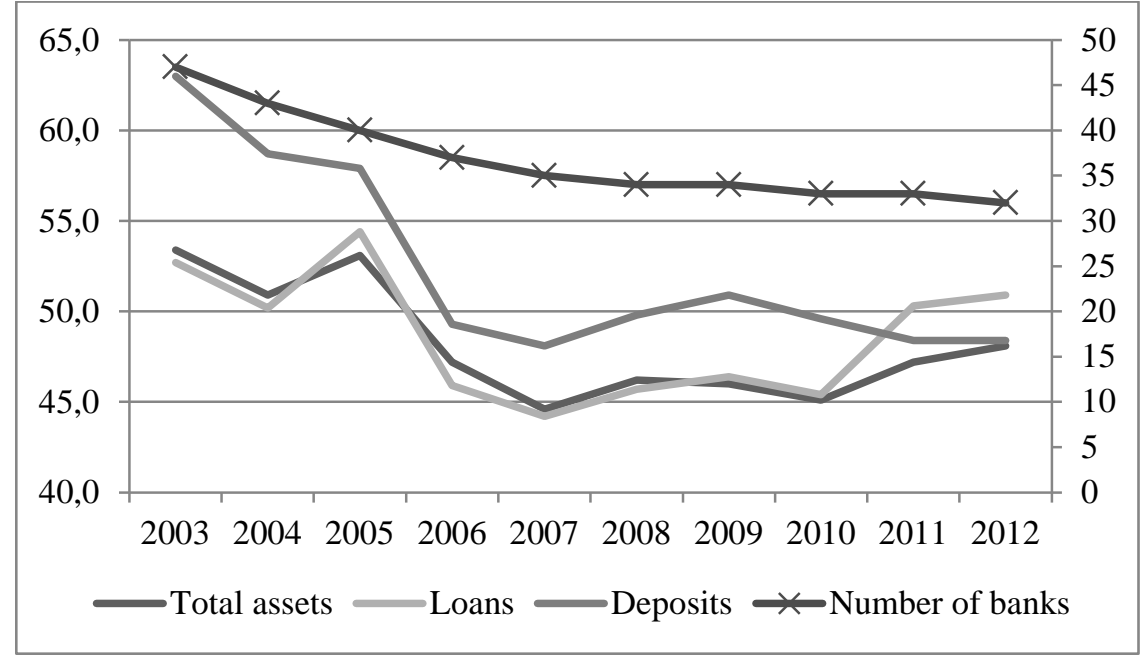

Source: NBS (2007-2012). Annual report and authors own calculation for 2003-2006

Our findings are consistent with studies that are in favour of the fact that reduced number of banks does not necessarily lead to increase in competition (for details see the section on literature review). As could be seen from Fig. 1 and 2, deposit activity is slightly concentrated in comparison to other two analysed indicators. In depth analysis shows that most of the deposits (and particularly residents' deposits) are concentrated in foreign banks, since four out of five largest banks are owned by non-residents (fifth bank - Komercijalna bank is state-owned). This fact is especially obvious by 2005. During the last two analysed years, the concentration according to deposit activity aligns with the other two (total assets and loans). There is also an interesting fact about the growth of the loan concentration of the five largest banks. Since 2010, loan concentration in the five largest banks has been growing especially in the segment of enterprises, public sector and public enterprises (at the end of the first quarter of 2013 this amount was $54.3 \%$ according to the NBS quarterly report for the first quarter of 2013, Narodna banka Srbije (2013)). Regardless of these facts presented, the concentration in the banking sector in Serbia is moderate and within normal limits for all analysed parameters, which proves our second hypothesis.

Although Fig. 1 and 2 give a general perspective of the level of concentration according to the defined segments, they are not informative enough, because they cannot be used for comparative analysis. For this reason we are introducing the tables 4-6 where we compare the number of credit institutions, $\mathrm{HHI}$ and $\mathrm{CR} 5$ with representative countries. When choosing the countries for 
comparison we included countries with similar economies (Croatia), former member of SFRY (Slovenia), neighbour countries (Bulgaria and Romania), other former transitional countries (Poland, Slovakia, Czech Republic, Hungary), but also the countries with extreme values of concentration indicators (Finland and Germany).

Table 4: The number of credit institutions in selected countries in the period 2003-20012

\begin{tabular}{lrrrrrrrrrr}
\hline Country & 2003 & 2004 & 2005 & 2006 & 2007 & 2008 & 2009 & 2010 & 2011 & 2012 \\
\hline Bulgaria & 35 & 35 & 34 & 32 & 29 & 30 & 30 & 30 & 31 & 31 \\
Czech Rep. & 77 & 70 & 56 & 57 & 56 & 54 & 56 & 55 & 56 & 56 \\
Germany & 2225 & 2148 & 2089 & 2050 & 2026 & 1989 & 1948 & 1929 & 1898 & 1869 \\
Hungary & 222 & 217 & 214 & 212 & 206 & 197 & 190 & 189 & 189 & 189 \\
Poland & 660 & 744 & 730 & 723 & 718 & 712 & 710 & 706 & 700 & 695 \\
Romania & 39 & 40 & 40 & 39 & 42 & 43 & 42 & 42 & 41 & 39 \\
Slovakia & 22 & 21 & 23 & 24 & 26 & 26 & 26 & 29 & 31 & 28 \\
Slovenia & 33 & 24 & 25 & 25 & 27 & 24 & 25 & 25 & 25 & 23 \\
Finland & 366 & 363 & 363 & 361 & 360 & 357 & 349 & 338 & 327 & 313 \\
Croatia & 41 & 37 & 34 & 33 & 33 & 34 & 34 & 33 & 32 & 31 \\
Serbia & 47 & 43 & 40 & 37 & 35 & 34 & 34 & 33 & 33 & 32 \\
\hline
\end{tabular}

Source: ECB database, EU Banking Structure, the Croatian National Bank for Croatia, National Bank of Serbia and authors calculation for Serbia

Table 4 shows that consolidation in the banking industry is present not only in Serbia but in other European countries. Table 4 also shows that the number of credit institutions in different countries varies dramatically. In these circumstances, $\mathrm{HHI}$ shows all its power and comparability, as it represents a synthetic measure that is comparable with any other sample. Due to these advantages, it is possible to compare Serbia, which at the end of $2012 \mathrm{had}$ only 32 banks, while Germany had 1869 banks.

Based on the data presented, it is clear that the Serbian banking sector is characterized by low concentration of both indicators. As measured by the $\mathrm{HHI}$, Serbia has a higher degree of concentration only from Germany and Poland (Table 5). Bearing in mind that the banking systems of Serbia and Germany are not comparable, it is better to look for countries with similar economic performance. In this sense it is better to compare Serbia to Croatia, but also with neighbouring countries, such as Bulgaria, Romania and other former transitional countries as Poland and Slovakia. Compared to each of these countries, Serbia has a lower $\mathrm{HHI}$, and thus lower degree of concentration. 
Ljumović I. et al.: Two Aspects of Concentration in Serbian Banking Sector

Table 5: HHI for selected countries in the period 2003-2012

\begin{tabular}{lrrrrrrrrrr}
\hline Country & 2003 & 2004 & 2005 & 2006 & 2007 & 2008 & 2009 & 2010 & 2011 & 2012 \\
\hline Bulgaria & $\mathrm{n} / \mathrm{a}$ & 721 & 698 & 707 & 833 & 834 & 846 & 789 & 766 & 738 \\
Czech Rep. & 1187 & 1103 & 1155 & 1104 & 1100 & 1014 & 1032 & 1045 & 1014 & 999 \\
Germany & 173 & 178 & 174 & 178 & 183 & 191 & 206 & 298 & 317 & 307 \\
Hungary & 783 & 798 & 795 & 823 & 839 & 819 & 864 & 828 & 848 & 872 \\
Poland & 754 & 692 & 650 & 599 & 640 & 562 & 574 & 559 & 563 & 568 \\
Romania & 1251 & 1111 & 1115 & 1165 & 1041 & 922 & 857 & 871 & 878 & 852 \\
Slovakia & 1496 & 1425 & 1076 & 1131 & 1082 & 1197 & 1273 & 1239 & 1268 & 1221 \\
Slovenia & 1496 & 1425 & 1369 & 1300 & 1041 & 1268 & 1256 & 1160 & 1142 & 1115 \\
Finland & 2420 & 2680 & 2730 & 2560 & 2540 & 3160 & 3120 & 3550 & 3700 & 3010 \\
Croatia & 1270 & 1363 & 1358 & 1297 & 1278 & 1309 & 1366 & 1362 & 1.401 & 1.427 \\
Serbia & 754 & 707 & 739 & 614 & 578 & 629 & 636 & 629 & 664 & 678 \\
\hline
\end{tabular}

Source: ECB database, EU Banking Structure, the Croatian National Bank for Croatia, National Bank of Serbia and authors calculation for Serbia

When another indicator of concentration is considered, the share of the top five banks in total assets, the situation is the same. Only Germany and Poland have lower values of this ratio (Table 6). Now we can conclude that the Serbian banking sector, despite the reduction in the number of banks, shows an exceptionally low concentration. The effect of concentration on the yield of banks can not be determined since the observed period was highly influenced by the economic crisis (see more at: Ljumović 2009).

Table 6: CR5 for selected countries in the period 2003-2012

\begin{tabular}{lrrrrrrrrrr}
\hline Country & 2003 & 2004 & 2005 & 2006 & 2007 & 2008 & 2009 & 2010 & 2011 & 2012 \\
\hline Bulgaria & n/a & 52,3 & 50,8 & 50,3 & 56,7 & 80,8 & 77,1 & 74,9 & 70,8 & 66,3 \\
Czech Rep. & 65,8 & 64,0 & 65,5 & 64,1 & 65,7 & 62,1 & 62,4 & 62,5 & 61,8 & 61,5 \\
Germany & 21,6 & 22,1 & 21,6 & 22,0 & 22,0 & 22,7 & 25,0 & 32,6 & 33,5 & 33,0 \\
Hungary & 52,1 & 52,7 & 53,2 & 53,5 & 54,1 & 54,4 & 55,2 & 54,6 & 54,6 & 54,0 \\
Poland & 52,0 & 50,0 & 48,5 & 46,1 & 46,6 & 44,2 & 43,9 & 43,4 & 43,7 & 44,4 \\
Romania & 55,2 & 59,5 & 59,4 & 60,1 & 56,3 & 54,0 & 52,4 & 52,7 & 54,6 & 54,7 \\
Slovakia & 66,4 & 64,6 & 67,7 & 66,9 & 68,2 & 71,6 & 72,1 & 72,0 & 72,2 & 70,7 \\
Slovenia & 55,2 & 59,5 & 59,4 & 60,1 & 56,3 & 59,1 & 59,7 & 59,3 & 59,3 & 58,4 \\
Finland & 81,2 & 82,7 & 82,9 & 82,3 & 81,2 & 82,8 & 82,6 & 83,8 & 80,9 & 79,0 \\
Croatia* & 61,6 & 64,9 & 64,9 & 64,1 & 63,9 & 64,8 & 65,2 & 65,3 & 66,4 & 66,9 \\
Serbia & 53,4 & 50,9 & 53,1 & 47,2 & 44,6 & 46,2 & 46 & 45,1 & 47,2 & 48,1 \\
\hline${ }^{*}$ Note: For Croatia used data on the share of the four largest banks & & & & & \\
\hline
\end{tabular}

Source: ECB database, EU Banking Structure, the Croatian National Bank for Croatia, National Bank of Serbia and authors calculation for Serbia 
Ljumović I. et al.: Two Aspects of Concentration in Serbian Banking Sector

\section{Conclusion}

Consolidation of the banking sector is a phenomenon, which is evident for the financial systems of the developed countries. Great number of banks disappeared from the global financial scene, i.e. important financial institutions, such as Bank One, Bank Barring et al. A similar phenomenon is observed with companies in other industries.

The period after 2000 is characterised by a dramatic changes in the banking industry in Serbia. Having this in mind we tried to analyse what happened with the concentration in this sector. Our first hypothesis referred to the whole financial system and we claimed that despite significant changes in the banking sector, the structure of the financial system did not drastically change. When proving this hypothesis, we encountered limitations regarding availability of data on other segments of the financial system prior 2007. However, bearing in mind that the capital market in Serbia is relatively young and that data from tables 1-3 show that Serbian financial system is bankbased as it was prior to the changes, we can conclude with a degree of certainty that the first hypothesis was confirmed.

There is a rule in transitional countries that level of concentration and reduction in number of banks is due to the inflow of foreign investment. Consequently, there is a question how this increase in concentration affects the banking market. So far there is no uniform attitude in the academic literature, because reduction in number of banks affects differently the level of concentration in different markets (somewhere increases, sometime decreases). The analysis of the $\mathrm{HHI}$ and the share of the top five banks in total assets shows that the Serbian banking sector is characterized by low concentration according to both indicators. This supports our second hypothesis.

Unfortunately, based on the data presented in Tables $3-5$, it is impossible to make a universal conclusion about whether reduction in number of banks positively or negatively affects the degree of concentration. In some countries, such as Serbia and Slovenia, reduction in number of banks decreased the level of concentration, while in other countries, such as Hungary and Germany, reduction in number of banks led to a slight increase in the concentration. There are cases, such as Croatia and Bulgaria, where the trend of changes cannot be determined, as it varies from year to year. This leads us to the conclusion that the degree of concentration in addition to the number of banks depends on many factors and for now these factors have not been identified in empirical analyses. However, the bigger problem is to determine whether and to what extent, the degree of concentration affects competition. The question is, whether the concentration is result of the fair 
Ljumović I. et al.: Two Aspects of Concentration in Serbian Banking Sector

competition or because of some other factors that will, over time, probably to be identified.

\section{Reference}

Adžić, S., Lazić J., Cvijanović J. M. (2005). High performance organization model, Industrija 33(2-3), 45-78.

Barjaktarović, L., Filipović, S., Dimić, M. (2013). Nivo koncentracije u bankarskoj industriji u zemljama centralnei istočne Evrope, Industrija 41(3), 39-54.

Beck, T., Demirguc-Kunt, A., Levine, R. (2006). Bank concentration, competition, and crises: First results. Journal of Banking \& Finance 30, 1581-1603.

Berger, A.N., \& Hannan, T.H. (1989). The price-concentration relationship in banking. Review of Economics and Statistics, 71(2), 291-99. doi:10.2307/1926975

Chakraborty, S., Tridip R. (2006). Bank-based versus market-based financial systems: A growth-theoretic analysis. Journal of Monetary Economics 53, 329-350.

Claessens, S., Laeven, L. (2003). What Drives Bank Competition? Some International Evidence. Journal of Money, Credit and Banking, Vol. 36(3), 564-583.

Demirguc-Kunt, A., Laeven, L., Levine, R. (2004).Regulations, Market Structure, Institutions, and the Cost of Financial Intermediation. Journal of Money, Credit and Banking 36(3), 593-622

Ergungor, O. E. (2004). Market- vs. bank-based financial systems: Do rights and regulations really matter? Journal of Banking \& Finance 28, 2869-2887.

Gelos, R.G., \& Roldos, J. (2004). Consolidation and market structure in emerging market banking systems. Emerging Markets Review, 5(1), 39-59. doi:10.1016/j.ememar.2003.12.002

Jansen, D., \& de Haan, J. (2003).Increasing Concentration in European Banking: a Macro-level Analysis.InResearch Memorandum WO. De Nederlandsche Bank.

Levine, R. (2002). Bank-based or market-based financial systems: Which is better. Journal of Financial Intermediation, 11(4), 398-428. doi:10.1006/jfin.2002.0341

Levy Y., Micco, A. (2007). Concentration and foreign penetration in Latin American banking sectors: Impact on competition and risk. Journal of Banking \& Finance31( 6), 1633-1647.

Ljubaj, I. (2005). Indeksi koncentracije bankarskog sektora u Hrvatskoj. Pregledi, P-21, listopad. Retrieved from http://www.hnb.hr/publikac/pregledi/p-021.pdf

Ljumović, I. (2009). Prelazak rizika u neizvesnost u uslovima globalne krize . Zbornik Matice srpske za društvene nauke, 129, 61-72. doi:10.2298/ZMSDN0929061L

Lončar, D., \& Rajić, V. (2012). Koncentracija i konkurentnost bankarskog tržišta Srbije - postojeće stanje i moguće promene pod uticajem buduće tržišne konsolidacije . Ekonomika preduzeća, 60(7-8), 372-385. doi:10.5937/ekopre1208372L 
Mamatzakis, E., Staikouras, C., Koutsomanoli-Fillipaki, N. (2005). Competition and concentration in the banking sector of the South Eastern European region. Emerging Markets Review 6, 192-209.

Marinković, S. (2006). Stepen konkurencije u bankarskom sektoru Srbije kao faktor konkurentnosti nacionalne ekonomije, Ekonomske teme 44(4-5), 71-84.

Marinković, S. (2007). Stanje i dinamika stepena koncentracije u bankarskom sektoru Srbije.Teme Vol. 31(2),. 283-299.

Miljković, M., Filipović, S., Tanasković, S. (2013).Tržišnakoncentracija u bankarskomsektoru - primer Srbije, Industrija41( 2), 7-25

Narodna banka Jugoslavije (2001). Godišnji izveštaj, Beograd. Retrieved from: http://www.nbs.rs/export/sites/default/internet/latinica/90/90 4/godisnii izvestaj 2001.pdf

Narodna banka Srbije (2003-2012). Godišnji izveštaj, Beograd.

Narodna banka Srbije (2013) Bankarski sektor, Izveštaj za prvi kvartal. Beograd. Retrieved from http://www.nbs.rs/export/sites/default/internet/latinica/55/55_4/kvartalni_izvestaj_ 13.pdf

Nathan, A., \& Neave, E.H. (1989). Competition and contestability in Canada's financial system: Empirical results.Canadian Journal of Economics, 22(3), 576-594. doi:10.2307/135541

Pavlović, V., Muminović, S. (2010). Značaj razvoja finansijskih tržišta za srpsku privredu. Industrija, 38(4), 41-67.

Schaeck, K. Cihak, M., Wolfe, S. (2009). Are Competitive Banking Systems More Stable?Journal of Money, Credit and Banking, Vol. 41(4), 711-734.

Shaffer, S. (1993). A test of competition in Canadian banking. Journal of Money, Credit and Banking, 25(1), 49-61. doi:10.2307/2077819

Uhde, A., Heimeshoff, U. (2009). Consolidation in banking and financial stability in Europe: Empirical evidence. Journal of Banking \& Finance 33(7), 1299-1311. 